\title{
Phytoprotection
}

\section{Histopathology of Fusarium wilt of staghorn sumac (Rhus typhina) caused by Fusarium oxysporum f. sp. callistephi race 3. II. Characteristics of opaque matter associated with extensive host cell and cell wall alterations \\ L'histopathologie de la fusariose du vinaigrier (Rhus typhina) causée par le Fusarium oxysporum f. sp. callistephi race 3. II. Caractéristiques d'une matière opaque reliée à l'altération prononcée des cellules de l'hôte et de leurs parois}

\section{Guillemond B. Ouellette, Danny Rioux et Marie Simard}

Volume 86, numéro 3, décembre 2005

URI : https://id.erudit.org/iderudit/013075ar

DOI : https://doi.org/10.7202/013075ar

Aller au sommaire du numéro

Éditeur(s)

Société de protection des plantes du Québec (SPPQ)

ISSN

0031-9511 (imprimé)

1710-1603 (numérique)

Découvrir la revue

Citer cet article

Ouellette, G. B., Rioux, D. \& Simard, M. (2005). Histopathology of Fusarium wilt of staghorn sumac (Rhus typhina) caused by Fusarium oxysporum f. sp. callistephi race 3. II. Characteristics of opaque matter associated with extensive host cell and cell wall alterations. Phytoprotection, 86(3), 175-187. https://doi.org/10.7202/013075ar

\section{Résumé de l'article}

On rapporte des observations en microscopie (photonique et électronique à transmission) de l'infection de plants de vinaigrier inoculés ou naturellement infectés par le Fusarium oxysporum f. sp. callistephi. L'un des aspects étudiés concerne la présence de matière opaque (MO) s'étant infiltrée dans les lamelles mitoyennes divisant les cellules de rayons et des fibres ou entre celles-ci, y longeant plusieurs espaces intercellulaires. Des liens ont été observés entre la MO intercellulaire et celle présente à l'occasion dans les parois secondaires et les espaces périplasmiques des cellules hôtes. Il y a eu augmentation graduelle de la MO vers l'écorce comme vers le sommet de la tige, et des altérations pariétales et cellulaires reliées à cette matière en fonction du temps après l'inoculation. On a noté dans la zone externe du xylème, en présence de la MO, l'hypertrophie et l'hyperplasie des cellules. La MO était encadrée par des lamelles minces et compactes, et, lorsque moins dense, elle est révélée contenir des particules opaques et autres fines structures; aucun indice de la présence antérieure ou actuelle d'organites intacts ou altérés dans la MO n'a été relevé Cette MO, comme celle d'apparence semblable accolée aux parois vasculaires, a capté l'anticorps monoclonal contre l'ADN complexée à l'or colloïdal. Dans les plants atteints de la fusariose, placés sur un milieu de culture gélosé avant d'être fixés pour y déceler les formes particulières de l'agent pathogène présentes, seuls des corps bien définis se trouvaient dans les cellules du xylème rendu à maturité et dans les espaces intercellulaires. Ces corps étaient entourés de structures membranaires ou d'amorces de parois et pourvus de particules opaques et d'îlots de fines structures. Certaines cellules du champignon présentes dans ou entre les cellules dans le même tissu, montraient le même genre de contenu. C0 la faveur de ces observations, nous postulons que la matière en question provient d'abord de l'agent pathogène et non de l'hôte. 


\title{
Histopathology of Fusarium wilt of staghorn sumac (Rhus typhina) caused by Fusarium oxysporum f. sp. callistephi race 3. II. Characteristics of opaque matter associated with extensive host cell and cell wall alterations
}

\author{
Guillemond B. Ouellette, Danny Rioux, and Marie Simard ${ }^{1}$
}

Received 2005-05-03; accepted 2006-02-20

PHYTOPROTECTION 86 : 175-187

Light and transmission electron microscopy observations of staghorn sumac plants inoculated or naturally infected with Fusarium oxysporum f. sp. callistephi are reported. One aspect of infection was the presence of large intercellular masses of opaque matter $(\mathrm{OM})$ in middle lamellae between ray cells and/or fibres, often bypassing several intercellular areas; similar OM confluent with the intercellular OM also occurred in secondary walls and in the periphery of numerous cells. A gradual increase in the abundance of the OM in host tissues vertically from the inoculation point and then radially was noted over infection time and was related to host wall and cell alterations. In the region of recently deposited tissue, the OM was associated with pronounced cell hyperplasia and hypertrophy. The OM was delimited by thin, compact bands, and when it was less compact, displayed opaque particles and other fine structures. No indications were obtained that it contained or had contained intact or altered organelles. The DNA probe bound to OM in middle lamellae and in cell periplasmic areas, and to material of a similar texture lining vessel walls. Samples from Fusarium-infected plants, incubated on an agar medium before fixing to determine from which elements the pathogens could develop, displayed bodies as the sole elements present in mature xylem cells and in intercellular areas. These bodies were delimited by membranous structures and profiles of a wall layer and contained opaque particles and areas of fine structures. Certain inter- or intracellular fungal cells in the same tissue frequently had similar content. In the light of these observations it is proposed that the OM is primarily of a pathogen rather than of a host origin.

Keywords: DNA labelling with a complexed monoclonal antibody, fungal wall irregularities, Fusarium wilt, vessel wall lining material.

[L'histopathologie de la fusariose du vinaigrier (Rhus typhina) causée par le Fusarium oxysporum f. sp. callistephi race 3. II. Caractéristiques d'une matière opaque reliée à l'altération prononcée des cellules de l'hôte et de leurs parois]

On rapporte des observations en microscopie (photonique et électronique à transmission) de l'infection de plants de vinaigrier inoculés ou naturellement infectés par le Fusarium oxysporum f. sp. callistephi. L'un des aspects étudiés concerne la présence de matière opaque (MO) s'étant infiltrée dans les lamelles mitoyennes divisant les cellules de rayons et des fibres ou entre celles-ci, y longeant plusieurs espaces intercellulaires. Des liens ont été observés entre la MO intercellulaire et celle présente à l'occasion dans les parois secondaires et les espaces périplasmiques des cellules hôtes. Il y a eu augmentation graduelle de la MO vers l'écorce comme vers le sommet de la tige, et des altérations pariétales et cellulaires reliées à cette matière en fonction du temps après l'inoculation. On a noté dans la zone externe du xylème, en présence de la MO, l'hypertrophie et I'hyperplasie des cellules. La MO était encadrée par des lamelles minces et compactes, et, lorsque moins dense, elle est révélée contenir des particules opaques et autres fines structures; aucun indice de la présence antérieure ou actuelle d'organites intacts ou altérés dans la MO n'a été relevé. Cette MO, comme celle d'apparence semblable accolée aux parois vasculaires, a capté l'anticorps monoclonal contre I'ADN complexée à l'or colloïdal. Dans les plants atteints de la fusariose, placés sur un milieu de culture gélosé avant d'être fixés pour y déceler les formes particulières de l'agent pathogène présentes, seuls des corps bien définis se trouvaient dans les cellules du xylème rendu à maturité et dans les espaces intercellulaires. Ces corps étaient entourés de structures

1. Natural Resources Canada, Canadian Forest Service, Laurentian Forestry Centre, 1055 du PEPS, P.O. Box 10380, Succ. Sainte-Foy, Québec (Québec), Canada G1V 4C7; corresponding author e-mail: gouellette@cfl.forestry.ca 
membranaires ou d'amorces de parois et pourvus de particules opaques et d'îlots de fines structures. Certaines cellules du champignon présentes dans ou entre les cellules dans le même tissu, montraient le même genre de contenu. À la faveur de ces observations, nous postulons que la matière en question provient d'abord de l'agent pathogène et non de l'hôte.

Mots clés: Anomalies de la paroi fongique, fusariose, marquage cytochimique pour I'ADN avec un anticorps monoclonal, recouvrements des parois vasculaires.

\section{INTRODUCTION}

Of the fungal wilt diseases known to affect staghorn sumac (Rhus typhina L.), Fusarium wilt caused by Fusarium oxysporum f. sp. callistephi (Beach) W.C. Snyder \& H.N. Hans. has been recognized only recently in the province of Québec, Canada (Ouellette et al. 2005). Although the pathogen is likely soil-borne and ingress plants through roots, external symptoms appear only on the smaller branches and twigs, and this seemingly only under certain weather conditions, as observed since 1993 (the year of its first observations in Québec). The symptoms are typical of other fungal wilt diseases, that is, internally, as discolorations of colonized wood, and externally, as browning and drooping of leaves in the acute disease stages and leaf yellowing and reddening in the less pronounced cases. An increased production of latex is also associated with infection (Ouellette et al. 2005).

Studies concerning the general histopathology of the disease, based on correlative light and electron microscope observations and cytochemical tests, were reported in Ouellette et al. (2005). In addition to mentioning particularities of pathogens cells, these observations dealt mainly with characteristics of extrinsic material in vessel lumina, including those apposed to vessel walls, and some aspects of tissue invasion and alterations. These ranged from peculiar breakdown of pit membranes of bordered pits, degradation of parenchyma cell walls, pervasion and alterations of vessel secondary walls by matter extending from their lining material and so on. These observations paralleled some of those made regarding other wilt diseases, in particular of elms infected by Ophiostoma novo-ulmi Brasier (Ouellette 1978; Ouellette and Rioux 1992, 1993; Ouellette et al. 1995, 1999a, 2004a) and of eggplant infected by Verticillium dahliae Kleb. (unpublished observations).

Other noticeable and seemingly unusual aspects of tissue invasion in staghorn sumac were related to the occurrence of large amounts of opaque matter in host walls and cells (Ouellette et al. 2004a). This situation was also comparable to that observed in elms and eggplants, inoculated with their respective pathogens, as mentioned above. In elms, this matter labelled with tritiated thymidine, following its injection in recently inoculated trees (Ouellette 1978), and in eggplant it was shown to contain particles of ribosomal appearance (unpublished observations). Observations of the wide occurrence of similar matter in infected sumac thus offered an opportunity to further investigate about its origin and nature. Hence, the objectives of the present study were to characterize the spatio-temporal relationship of the opaque matter in question with host cell and cell wall alterations, as based on sequential sampling following inoculation, and of its possible connections with pathogen cells. To this end, parallel light and transmission electron microscope observations were conducted, using cytochemical tests for chitin and DNA. The direct or indirect host cell reactions following tissue invasion are presented elsewhere.

\section{MATERIAL AND METHODS}

The study material, the sampling data, methods of tissue treatments, and techniques of cytochemical tests have been described in detail in Ouellette et al. (2005). Present data also concern inoculated and naturally infected material. The observations from inoculated material were based on samples taken at $5 \mathrm{~cm}$ above the inoculation point to the tip of advancing streaks in the xylem $(30 \mathrm{~cm}$ in the most pronounced cases), up to $35 \mathrm{~d}$ after inoculation (dpi). To determine the kind of pathogen elements that could, in already colonized tissue, resume or continue their development in a less restricted manner, some samples were incubated for 1 to $4 \mathrm{~d}$ on a $2 \%$ potato dextrose agar medium before fixing. In addition to the cytochemical tests for chitin, as described in Ouellette et al. (2005), tests for localizing DNA were conducted with a colloidal gold-complexed monoclonal antibody to this nucleic acid. The anti-DNA monoclonal antibody (mab) was a mouse mab IgM antibody against single and double-stranded DNA (Boehringer, Mannheim, Germany). For labelling, sections on formvar-coated nickel grids were floated on a drop of $0.01 \mathrm{M}$ phosphate-buffered saline (PBS), $\mathrm{pH} 7.2$, containing $3 \%$ bovine serum albumin (BSA), for $10 \mathrm{~min}$ at room temperature, and then incubated with the antiDNA mab (5 $\mu \mathrm{g} \mathrm{mL}^{-1}$ in PBS-1\% BSA) for $1 \mathrm{~h}$ at $37^{\circ} \mathrm{C}$. After washing $(3 \times 10 \mathrm{~min})$ with PBS containing $0.1 \%$ Tween-20, the grids were incubated with goat antimouse IgM coupled to $15 \mathrm{~nm}$ gold particles diluted according to the manufacturer's recommendation (BioCell, Cardiff, UK). Control tests included: 1) incubation with the anti-DNA antibody, previously adsorbed with DNA from calf thymus; 2 ) omitting the primary antibody in the procedure.

\section{RESULTS}

\section{Location and extent of tissue invasion}

Light microscope observations. Fungal cells of varying sizes occurred in vessel elements close to the inoculation point, presumably those that were first invaded, but reaching from these to the stem apex, the vessels mainly contained wall lining material and diversely shaped elements connected to fine filaments and/or bands of OM (Fig. 1a, b). A prominent feature in these regions was the occurrence of large amounts of OM in middle lamellae of ray cells and of 


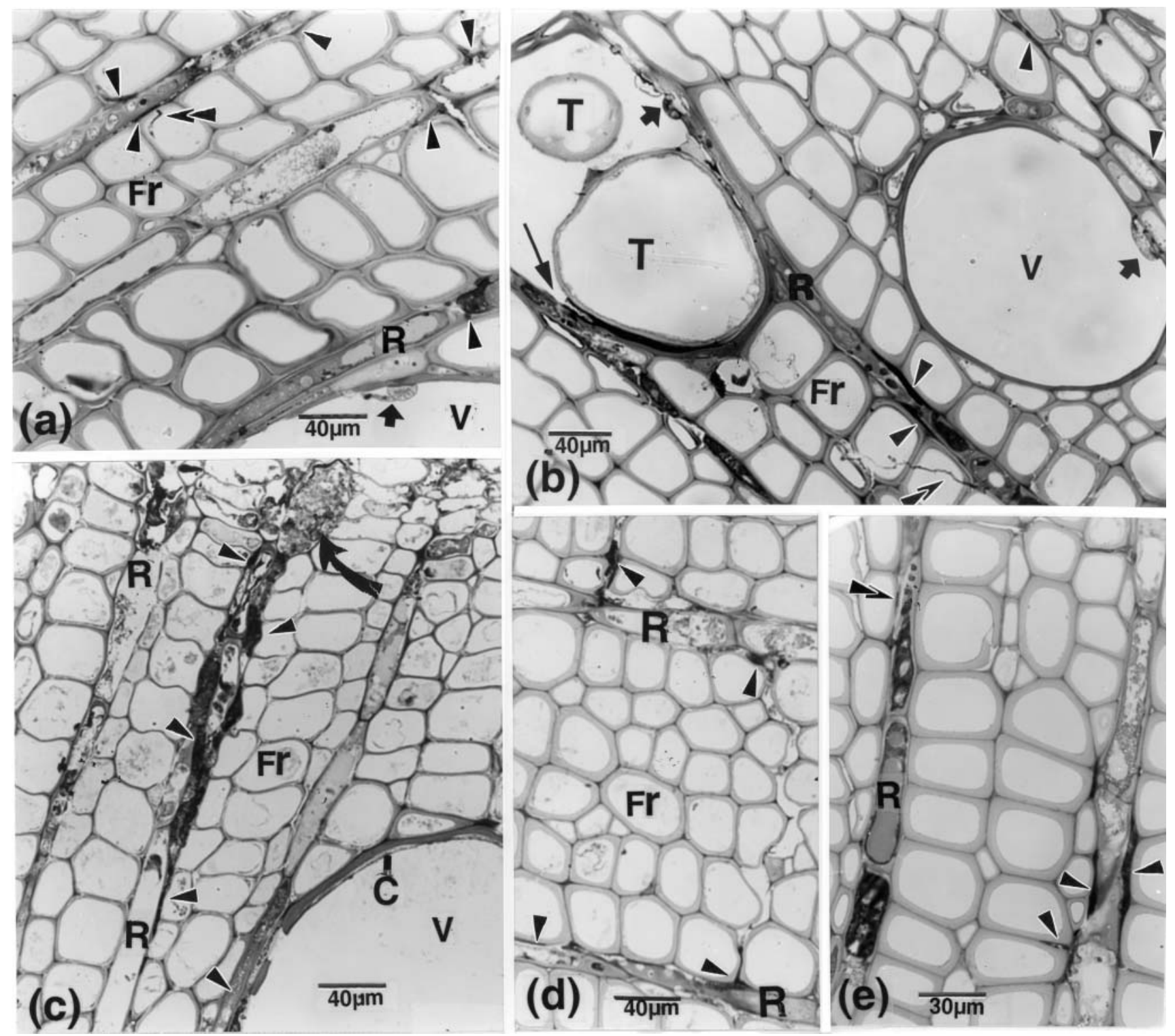

Figure 1. Light microscopy (LM) of R. typhina-F. oxysporum interactions in inoculated samples (IS). (a, b):. opaque matter (OM) is present in middle lamellae (arrowheads) of ray and adjoining fibres. Microhyphal-like elements (superimposed arrowheads), seemingly connected to this OM, extend through fibre cell walls. Elements, with lighter or denser contents, affixed to vessel walls, are confluent with bands of OM along or in host walls or with hyphal-like elements (short arrows). In $\mathbf{b}$, the tylosis is surrounded by $\mathrm{OM}$, some impinging upon the ray cell walls (thin arrow). (c): $4 \mathrm{dpi} / 5 \mathrm{~cm}$. The intercellular OM bands and masses (arrowheads) bypass several cells reaching the cambial region in which hypertrophied (curved arrow) and/or hyperplastic cells occur. The inner walls of some of the affected cells (labelled R-cells) are locally obliterated. (d): $4 \mathrm{dpi} / 5 \mathrm{~cm}$. OM (arrowheads) is present in and between fibre cell walls, in a path extending from one row of ray cells to another. (e): $8 \mathrm{dpi} / 3 \mathrm{~cm}$. OM occurs between a row of ray cells (right-hand side) containing altered cytoplasm, compared with cells (left-hand side) filled with tannin-like components, and between which only traces of OM are distinguishable (superimposed arrowheads). C, vessel wall lining material; Fr, fibre; OM, opaque matter; $R$, ray cell; $T$, tylosis; $V$, vessel element. 
adjacent rows of fibres (Fig. 1a-d). This OM had connections with similar matter in vessel lumina, or through ruptures in vessel walls, at junctures with paratracheal cells (Fig. 1b). Microhyphal-like elements, connected to or bifurcating from intercellular OM extended into or across adjoining cells (Fig. 1a, b).

Radially, OM occurrence between ray cells and its association with host wall alterations were progressively more important from the invaded vessels outward to the cambial region (Fig. 1c), with the degree of invasion decreasing proportionally with increasing distances from the inoculation point. Various tissue modifications, including cell hyperplasia and hypertrophy (Fig. 1c), occurred associated with the presence of $\mathrm{OM}$ in the layers of newly differentiated cells. Tangentially, the infection was generally confined by reacting ray cells (Fig. 1e); however, in some inoculated twigs left to overwinter, the growth ring was completely colonized the following spring and these did not leaf out.

TEM observations. Examinations in TEM of samples corresponding to those used for LM showed that OM spanned long distances in middle lamellae and intercellular areas along ray cells, often bypassing several fibres (Fig. 2a1-2a3). Bands and masses of often juxtaposed OM were easily distinguishable from host wall layers, by their generally uniform, much greater opacity (Fig. 2a, b). One or more small opaque bands penetrating middle lamellae and/or secondary walls were traceable to the intercellular matter (Fig. 2b-e). $\mathrm{OM}$ masses were in close contact with host wall over most of their lengths, with their extremities ending up as either thin bands in still intact walls, or bands therein engulfed wall portions (Fig. 2 b, c). In cases of localized discontinuities in the OM bands or masses, some degradation and splitting of host walls were apparent (Figs. 2e, 3a). The plasmalemma and/or tonoplast were still visible in ray cells and fibres adjoining OM-invaded walls, although their content was appreciably altered (Fig. 2a, e). Affected cells did not contain opaque-like matter, except occasionally in the cell periplasmic area, but which generally connected with OM in adjacent host walls (Figs. $2 \mathrm{~d}, 3 \mathrm{~b}$ ). The cell plasmalemma in these cells was only locally altered or obscured in presence of OM, which extended at points into the cell content. One of the reactions noted in response to OM occurrence was the deposition of new wall material over OM-associated ruptures in the walls or all along the native wall in ray cells (Fig. 3a). OM masses were also embedded in this new layer (Fig. 2a).

\section{OM characteristics}

The OM masses were usually confined by thin, distinct bands, which were particularly noticeable when the OM was less compact or faced void spaces (Fig. 4a, b). Frequently, only one side or portion of the mass was clearly bound (Fig. 4b); in this instance, the OM-host wall interface was marked by arrays of fine structures or profiles of an apparently discontinuous band. Also, distinct opaque bands delimiting the OM penetrating host cell secondary walls and that present in the adjacent cell periplasm appeared to be lacking or obscured (Figs. 2c, 4b).
Due to the high opacity and compactness of OM, its structural composition and organization were not easily perceptible, except in less dense areas where it displayed fine structures mixed with bodies of more or less regular sizes (Fig. 4a, b). Occasionally, thin bands, similar to those delineating the OM masses and occurring similarly in middle lamellae, circumscribed numerous vesicular bodies, some of which occurred in close contact with the bands (Fig. 4c). Connections, with fungal cells, of OM extending into host walls were also observed (Fig. 5a). The opaque matter in this type of cells clouded nuclear areas and ribosomes, and their walls were almost free of labelling for chitin, contrary to the strongly labelled fungal walls that did not contact host walls.

Similar OM was not observed in healthy or waterinjected samples, except in a single case, in the cambial area of a twig whose bark had been visibly invaded by another fungus (not illustrated).

\section{DNA labelling}

These results were obtained from samples collected early after inoculation and at 5 or $10 \mathrm{~cm}$ from the inoculation point. The gold-complexed anti-DNA mab clearly attached to vessel wall lining material (VWLM), to regions of the large or smaller intercellular homogeneous OM masses, to OM bodies of various sizes and shapes present in the periplasm of parenchyma cells and to OM extensions across cell walls into the cell lumen or cellular content (Figs. 5b$\mathrm{g}$, 6a, b). In regions where the OM penetrated host cell secondary walls, it was associated with vesicularlike bodies (Fig. 5c, d). Also, some periplasmic OM masses contained lighter areas of fine structures which labelled less intensely than the adjacent portions (Fig. $5 \mathrm{~g}$ ). In addition to those associated with OM, gold particles were dispersed or occurred locally more concentrated over the altered host cytoplasm, some of which likely originated from altered organelles, such as nuclei and the often hypertrophied plastids (Figs. $5 g, 6 a$ ). The lucent layers delimiting the bodies in cell periplasm and the VWLM were mostly free of gold particles (Fig. 6a, b). In altered or almost intact host nuclei, labelling was mostly associated with heterochromatin (Fig. 6a), whereas only few particles ornamented mitochondria (intact or altered). Gold particles also occurred over opaque bodies and material in seemingly reacting cells in vessel elements, shortly after inoculation (Fig. 6c). Other cells were filled with dense content characterized by numerous opaque bodies intermixed with finer, less opaque components (Fig. 6d). These cells had striated walls in regions contacting other type of material in vessel lumina or host walls, associated with their alterations. Host cell walls, void spaces free of content, and apparently normal cell cytoplasm were mostly free of gold particles (Fig. 6a, b), and were similar in this respect to controls (not illustrated).

\section{Infected samples incubated on PDA}

Except for the situation described below, most mature xylem cells in these samples had sparse content and if so organelles were distinguishable although much degraded, including nuclei generally showing an altered envelope (Fig. 6e) or hypertrophy (not illustrated) and dispersed or larger masses of 


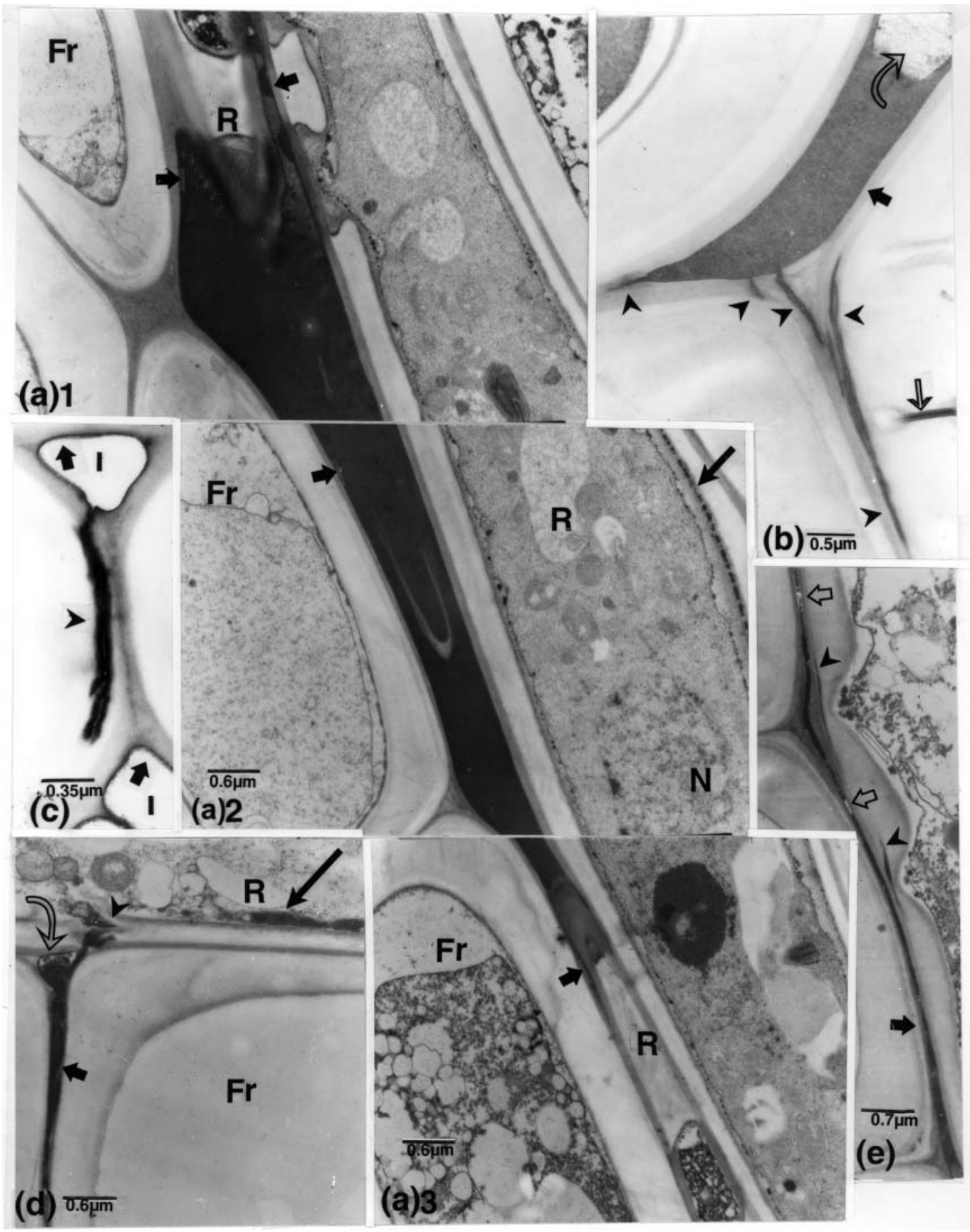

Figure 2. TEM of opaque intercellular matter in inoculated $R$. typhina, except c, naturally infected. (a1-a3): the OM masses (in three confluent, cut-up portions) are bound by locally discernible opaque bands (short arrows), bypassing intercellular areas between ray cells and fibres. The middle lamella is intact at the OM extremities (a1, a3). Spots of OM (a2, long arrow) are present in an inner new wall-like layer in the long ray cell having dense content and an altered nucleus. (b): small bands (arrowheads) extend at the tip of an intercellular OM mass (short arrow) or at right angles from it into an adjoining middle lamella. Amorphous matter is included in the mass (curved arrow). The thin, light arrow = a pinch in the section. (c): the periphery of intercellular areas is lined with bands of OM (arrows), from which other paired bands (arrowhead) extend across the still intact, ray cell secondary wall. (d): a stretch of OM (short arrow) in a fibre middle lamella is continuous with similar, clearly delimited matter (curved arrow) in an intercellular area, and across a rupture in the walls of an adjacent ray cell (arrowhead). OM occurs nearby (long arrow) in the cell periplasm. Except in this and one other confluent region, the plasmalemma was distinct in the cell. (e): OM extends through a ray cell middle lamella (dark arrow) and secondary walls (arrowheads), which bypassed eight fibres; it was also present in walls on the other side of the cell. Gaps are visible at points of OM discontinuity (light arrows). The cell content is altered, but the plasmalemma location is distinguishable. Fr, fibre; I, intercellular area; N, nucleus; OM, opaque matter; $R$, ray cell. 

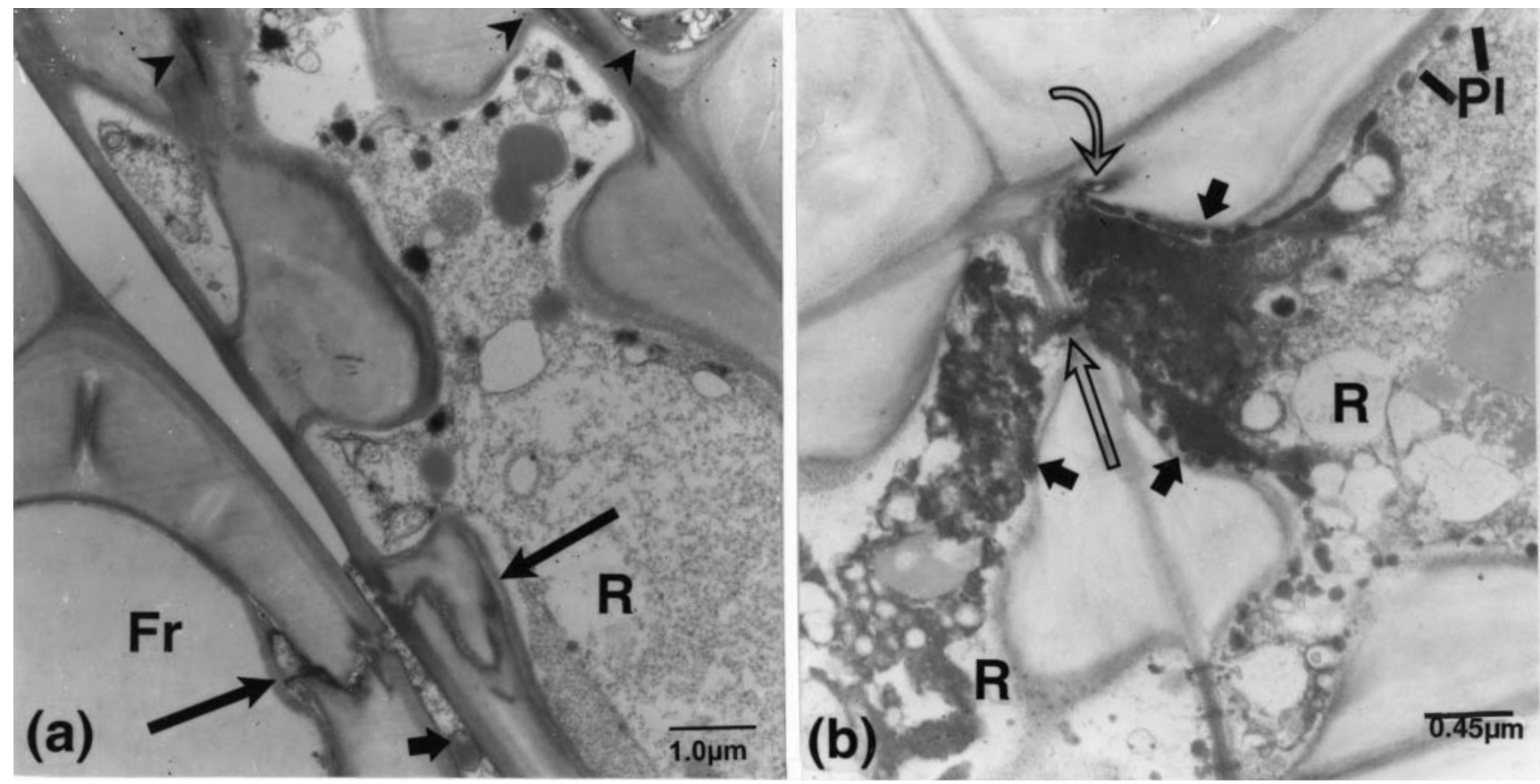

Figure 3. TEM of sumac inoculated samples. (a): new wall layers have been deposited in ray and fibre cells, covering wall ruptures (long arrows) that are associated with OM, next to an altered middle lamella (short arrow). (b): OM masses (short arrows) occur in the periphery of contiguous ray cells, bridged to one another by a similar band (long arrow) across the pit membrane. This OM is also continuous with similar matter in the cell secondary wall (curved arrow). Except in areas of massive OM occurrence, the plasmalemma and a thin, inner wall-like layer are discernible in these cells. Fr, fibre; OM, opaque matter; PI, plasma membrane; $R$, ray cell.

opaque content. In these types of samples, particularly those incubated for more than $24 \mathrm{~h}$, a variety of structurally organized elements were observed that were not present as such in non incubated samples. First, cells with large amounts of opaque content, considered as irregular, occurred in middle lamellae, differing from those of rare occurrence in samples that were not incubated (not illustrated). Of particular interest was the occurrence of many elements as the only remaining components in mature host cells, including fibres, in areas corresponding to the cell periplasm, and in intercellular spaces (ordinarily devoid of content, as for fibres) (Fig. 7a-d). Those cells and elements showed some analogy of content and were delimited by a single opaque band or by thin, irregular walls that were heavily pervaded by filamentous structures. Hence, these elements differed from fungal cells in culture, as also did their content from normal or altered host cell cytoplasm. Even the cells that were delimited by more typical layers were considered as atypical, displaying large, poorly delimited central areas containing units or aggregates of tiny particles mixed with filamentous structures (Fig. 7a, e). In comparison with distinct ribosomes, these particles were less opaque, seemingly smaller and often somewhat aligned in chains.

Another prominent feature in this type of material was that many fungal cells contained large electron opaque bodies (EOBs) that were seemingly not included in vacuoles, or at least not well circum- scribed by a membrane (Fig. 8a). Other cells contained in addition less opaque bodies and areas of lighter material delimited by opaque bands which, in some cases, appeared as an ingrowth of the plasma membrane (Fig. 8b). Still other cells mostly contained particles identifiable as ribosomes, a content which overall was not clearly delimited by membrane (Fig. $8 \mathrm{c})$, as compared to its obvious presence in other cells (Fig. 8a, b). The walls of these fungal cells were permeated by fine fibrillar structures (Fig. 8a, b); these often extended externally into masses of opaque matter, connecting with that of other cells (Fig. 8c). Also, the walls in these cells were irregular, discontinuous or desquamated (Fig. 8a-c).

\section{DISCUSSION}

The present observations are considered to strongly corroborate previous ones of similar OM occurrence in elms infected with Dutch elm disease (Nicole et al. 1994; Ouellette 1978; Ouellette and Rioux 1992, 1993; Ouellette et al. 2004a). In addition to its progressive occurrence with infection time, OM in sumac was also associated with host cell and cell wall alterations, and was often concomitant with cell reactions. In assessing whether this matter was of fungal or of host origin, its obvious invasive nature has to be taken into consideration. To say the least, one cannot assume that it simply corresponded to disintegration products, and/or to a mixture of free enzymes, as one of 


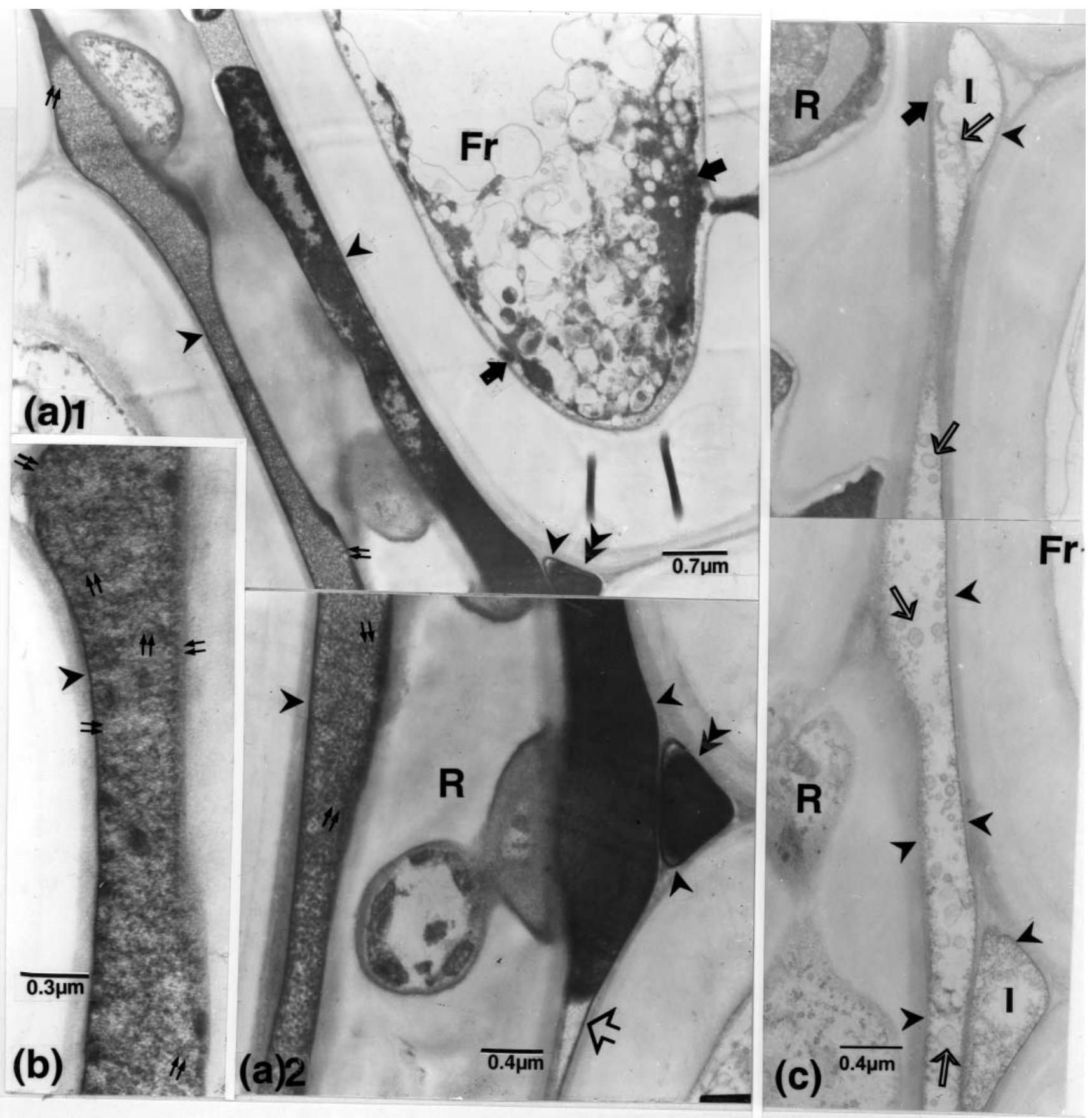

Figure 4. TEM characteristics of intercellular OM in sumac inoculated samples. Arrowheads point to opaque bands delimiting OM masses or content. (a1, a2, the latter being a magnified contiguous portion of the former): a compact OM mass bypasses another transversely sectioned mass (superimposed arrowheads) in an intercellular space. One of the opaque bands (light arrow) extends on one side of the dislocated middle lamella; small circular bodies (paired small arrows) can be distinguished throughout in the less compact OM. OM masses overcasting the plasmalemma or present in the outer cell cytoplasm (short arrows) also occur in one fibre. (b): an area, similar to that shown in a2 (left part) displays clumps and smaller dense particles in a matrix of filamentous structures, including circular bodies (paired small arrows). An imprecise thin layer delimits the right side of the mass, vs. a distinct one on the other side (arrowhead). (c): numerous vesicular bodies (thin light arrows) occur intercellularly, bound by fine bands (arrowheads), are associated with eroded wall portions, marked at one point by a notch (dark arrow). Fr, fibre; I, intercellular area; OM, opaque matter; $R$, ray cell. 


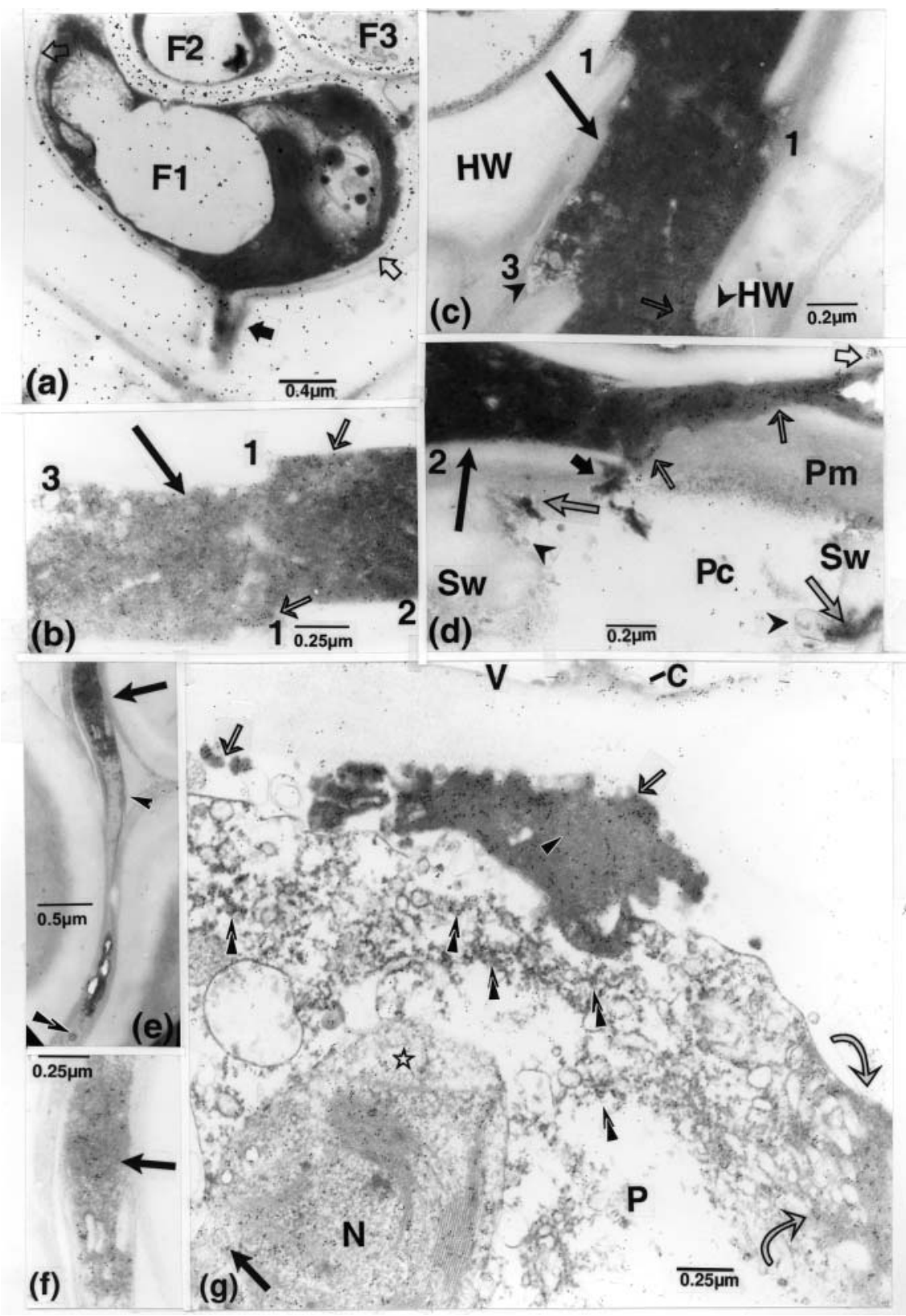

Figure 5. TEM of inoculated R. typhina, except a, naturally infected. (a): labelling for chitin. An opaque peg-like structure (dark arrow), included in a fibre wall, is connected to cell F1; in an underexposed print, the opaque content of this cell showed a nucleus and other normal organelles. Gold particles, sparse over the F1 wall contacting the host cell wall (between light arrows), are numerous on other portions and on F2 and F3 walls. (b-f): treatment with a gold-complexed anti-DNA mab. Prints (b, $\mathbf{f}, \mathbf{g})$ were underexposed to better illustrate gold particles. (b-d): cut portions of a mass of homogenous OM (long arrows) (with points of correspondence in $\mathbf{b}$ and $\mathbf{c}$ being indicated by numbers 1 and 3 , and of junction between $\mathbf{b}$ and $\mathbf{d}$ by the number 2 ) which spanned at least the length of three cells. Gold particles occurred all over the OM, concentrated over patches of fine matter (thin light arrows). The middle lamella is dislocated (c) and incursions of the OM into secondary walls are marked by vesicular-like structures (arrowheads in $\mathbf{c}$ and $\mathbf{d}$ ). In $\mathbf{d}$, the short dark arrow = OM reaching from the intercellular one across the Pm into the pit chamber; long light arrows = OM seemingly breaching upon the Sw; and short light arrow = a detached patch of OM. (e): an element (arrow), delimited by a thin band (arrowhead), and with opaque content and vesicular-like structures (superimposed arrowheads) extends through a middle lamella, bypassing intercellular areas between fibres. (f): enlarged portion of e (indicated by arrow) showing concentrations of gold particles over the opaque matter. $(\mathbf{g})$ : in the periphery of a parenchyma cell with altered content, small and larger OM masses (thin arrows) are clearly labelled, with the more lucent portion in the greater mass seemingly less strongly labelled (arrowhead). The plasmalemma located between such matter and that reaching into the altered cell content (curved arrows), is visibly absent, but distinguishable nearby. Gold particles have also attached in noticeable numbers: to regions of a plastid (star) and its proliferated portion (dark arrow); to other smaller dispersed opaque bodies in the cell content (superimposed arrowheads); and to the vessel wall lining material (C). F, fungus; HW, host wall; N, nucleus; OM, opaque matter; $P$, parenchyma cell; Pc, pit chamber; Pm, pit membrane; Sw, vessel secondary wall; V, vessel element. 

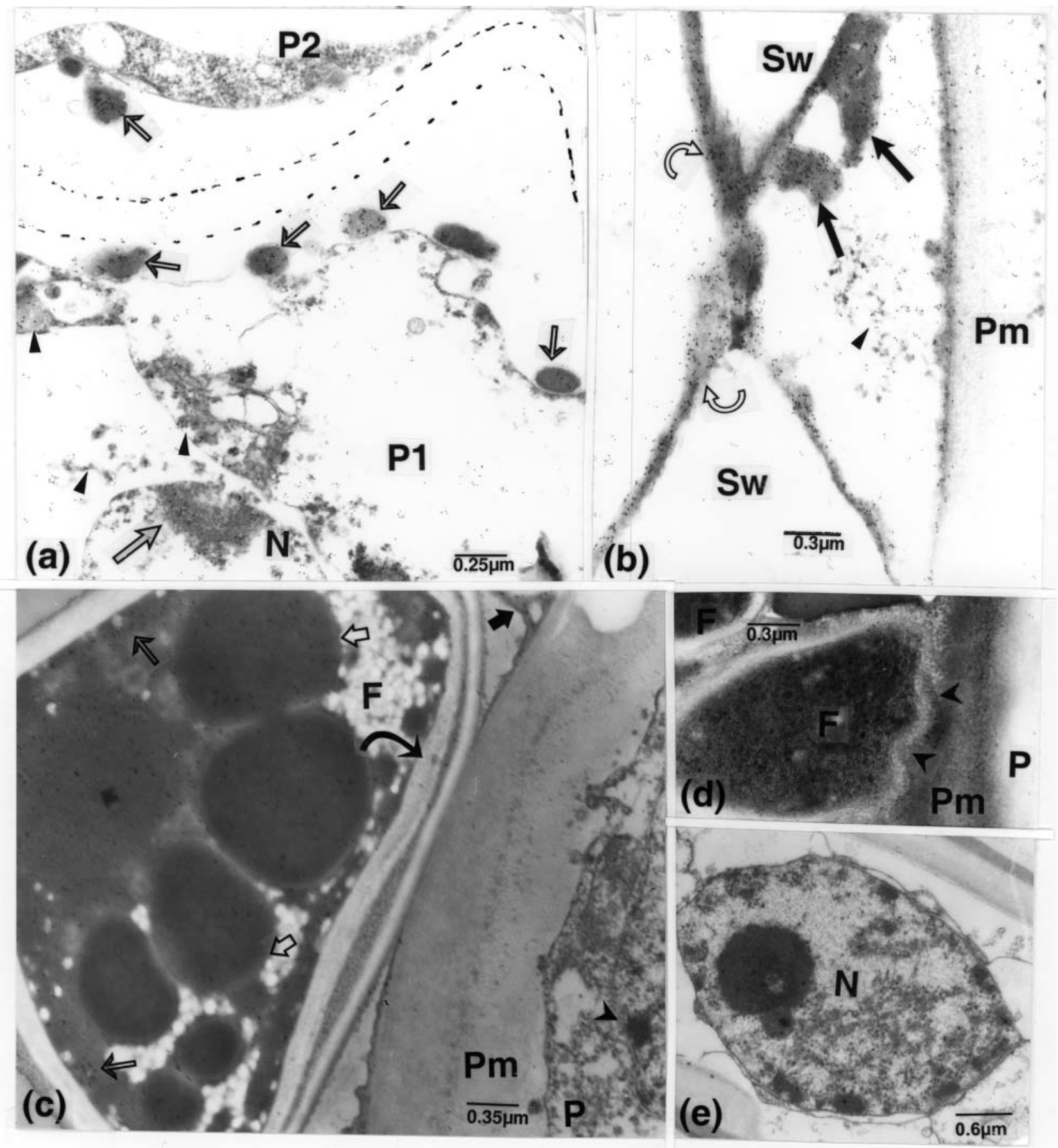

Figure 6. TEM of inoculated R. typhina samples, except $\mathbf{e}$. Microphotographs $\mathbf{a}$ and $\mathbf{b}$ were underexposed to better illustrate the occurrence of gold particles of the DNA probe. (a): concentrations of gold particles occur over several masses of OM (thin arrows) in the periplasmic areas of parenchyma cells. In P1, the probe has bound to host nucleus heterocromatin (arrow) and to other cytoplasmic remnants (arrowheads). The thin lucent layer, surrounding these masses, and the less disintegrated cytoplasm in P2 are free of gold particles. Dotted lines delimit the cell wall regions. (b): concentrations of gold particles likewise ornament the VWLM (curved arrows) including its projections (arrows) in the pit chamber. This lining material is texturally similar to that present in the cell peripheries (as in a), and similarly delineated by an unlabelled, thin lucent layer. Most of the particles present in the pit chamber and the parenchyma cell periplasm are associated with traces of OM (arrowhead). (c): labelled opaque bodies (short, light arrows) and similar confluent matter (thin arrows) in a F-cell showing a double layered wall (curved arrow) in a region contacting a pit membrane. Gold particles were absent elsewhere on the section except over the heterochromatin in the altered nucleus (arrowhead) in the parenchyma cell and over the VWLM (dark arrow). (d): a F-cell in contact with a Pm is pervaded by fine structures reaching into the dislocated membrane (arrowheads). The dense cell content displays numerous opaque bodies and fine components. (e): shows a host nucleus with altered nuclear envelope, surrounded by altered cytoplasm. F, fungus; N, nucleus; OM, opaque matter; P, parenchyma cell; Pm, pit membrane; Sw, vessel secondary wall; VWLM, vessel wall lining material. 
the explanations given by others for seemingly similar matter (Park et al. 2000). If the OM corresponded to altered host cytoplasm, this would not explain how it can infiltrate intact middle lamellae over long distances in a mostly homogeneous, compact form. When this intercellular matter was less compact, it still appeared to be homogeneous, including high numbers of small vesicular bodies enclosed by bands similar to those delimiting the compact OM. Indeed, disintegrated host cytoplasm, as shown in several present illustrations (for example, Fig. 2a, d), does not compare with the present OM.

The present observations reinforce the hypothesis, as already expressed for other systems and supported by similar observations (Ouellette and Baayen 2000; Ouellette and Rioux 1993; Ouellette et al. 1995, 1999a, 2004a, 2004b, 2004c, 2004d), that the OM occurrence primarily relates to the pathogen, as: 1) OM, including that of the VWLM, was also connected to fungal cells, and often by means of microfilaments (see also Atstatt 2003, showing some endophyte-like fungal cells with their walls pervaded by similar filamenatous structures); and 2) close similarities noted between OM present in host walls or in periplasmic areas, that of the VWLM, and content of some fungal cells and elements (compare Figs. $6 d, 7 d, 8 c$ and element in Fig. 7a). Another point worth considering is that the anti-DNA mab probe strongly attached to opaque content and bodies in fungal cells and to OM, next to host cells and cell walls over which only sparse particles occurred, even in the vicinity of altered organelles that would normally contain DNA. These results seem to eliminate the possibility that this pronounced labelling of OM was attributable to DNA fragments having potentially been released from those organelles and adsorbed by other matter. Nevertheless, these results still raise a number of questions that require further investigations, but they should be considered as significant, although astonishing. Indeed, the probe attached uniformly to analogous matter in specific locations, and more so than to altered DNA-containing host organelles, whereas in control samples only sparse gold particles occurred as background over the section, and this mainly in void spaces. In other studies using the same test (Chamberland 1994), the probe was also found to specifically bind to DNA-containing organelles, including the nuclear regions which almost completely filled fungal cells of Ophiostoma novo-ulmi growing through millipore membranes of low porosity (Ouellette et al. 1999a). Analogous OM, associated with similar tissue alterations in elms infected with this pathogen and injected with tritiated thymidine, became highly labelled as shown by autoradiography (Ouellette 1978; Ouellette and Rioux 1993). Observations of the apparent absence of a nuclear envelope in some fungal cells in the present study are also similar to those of 0 . novo-ulmi and of other F. oxysporum f. spp. (Chamberland and Ouellette 1977a; Charest et al. 2004; Ouellette et al. 2004c). It is not impossible that the components of high opacity in this OM concealed some structural DNA (see Fig. 5a). It is known that in spermatozoids of Bryophytes and Pteridophytes, the nucleus becomes very opaque, following the re-alignment of DNA into arrays of straight filaments (Carothers 1973;
Renzaglia et al. 2002). This possible re-alignment of DNA could represent a state of quiescence, but this compound had to be synthesized beforehand.

Fine filamentous-like structures were also connected to OM. Similar structures often pervaded fungal walls and extracellular matter, and then seemed to stretch freely over void spaces or into the host cell walls. A similar association was equally observed in other fungal wilt pathogens (Nicole et al. 1994; Ouellette et al. 1995, 1999b, 2002).

The possible presence of DNA in the OM does not necessarily imply that this matter would contain all the complements essential to regenerate cells at any one point. In an attempt to elucidate this question, TEM observations were made of samples fixed before and after incubation on PDA from shrubs proven to be infected solely by F. oxysporum f. sp. callistephi. Thus, some bodies, present as single elements in intercellular and periplasmic locations of cells (often fibres), displayed cytoplasmic-like components that were delimited solely by thin membranous structures. In this situation, one would need to explain how the integrity and cohesiveness of these elements were maintained. Indeed, it is current knowledge that once a cell plasmalemma and other membrane systems are altered, the cell becomes necrotic, including ribosome disintegration. It can be presumed that pathogen cells might better withstand these alterations than host cells. As the plasmalemma and other membranes were reasonably well preserved in more typical fungal cells present in the vicinity of elements showing anomalies in membranes, it appears that fixation of the material was adequate, at least comparable to similar material fixed by the same procedures and deemed to be valid points of reference. It would be improbable to discover that these elements were simple artefacts of fixation procedures as they have been seen in more than one system (as referred to above). Some of the bodies were also partly delimited by a wall-like band, and their content was structurally more comparable to that of normally walled fungal cells than to host cell content, including nuclei, which in some cases were still relatively intact. If these bodies belonged to fungal elements and had evolved from the $O M$ in question, this would imply that at least some of this $\mathrm{OM}$ could proceed to further development.

Other particular features concerning the pathogen were shown, such as irregularities in their wall layers and, under certain conditions, their content of EOBs. These bodies, clouding other structures, were seemingly not included in vacuoles. Similar bodies were observed in 0 . novo-ulmi cells infecting elms, but more rarely in culture, and shown to become slightly labelled with tritiated thymidine (Chamberland and Ouellette 1977b). The anti-DNA probe also attached to opaque bodies in the pathogen cells. EOBs have also been observed in young cells in other fungi, and were perceived to contain "lipoidal material in possible association with a protein matrix" (Garrison et al. 1977). In this respect, our observations have also shown that the EOB content may be heterogeneous (not illustrated). However, the opaque bodies in fungal cells may not all be connate (this is illustrated in Fig. 8b), particularly when they occur in locations 


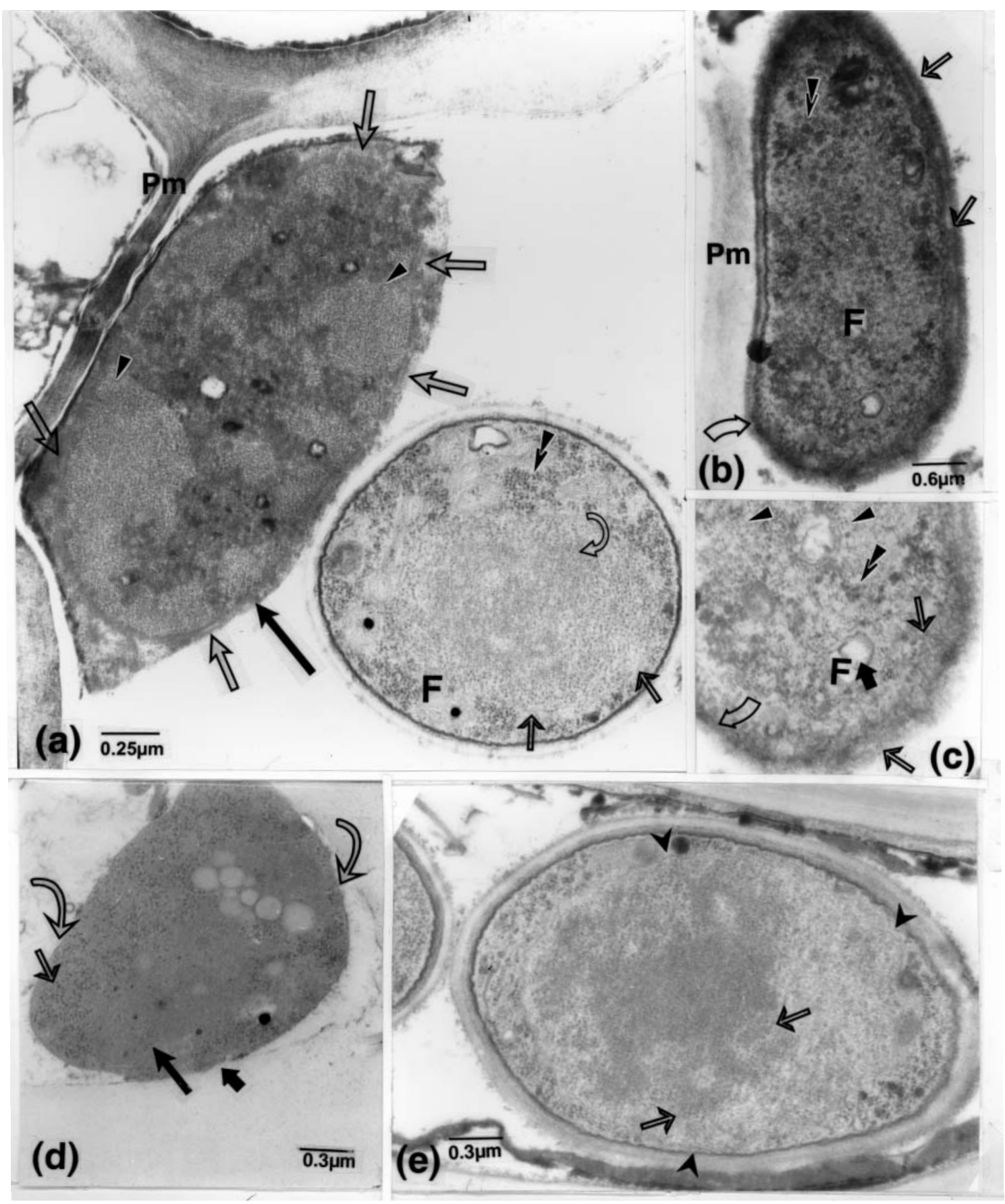

Figure 7. TEM of naturally infected sumac samples, incubated 1 or $2 \mathrm{~d}$ on an agar medium before fixing. (a): the outer poorly delimited (thin, light arrows) central region of the F-cell, well delimited by a plasma membrane, contains particles that are smaller and less opaque than the ribosomes (superimposed arrowheads). The adjacent large element (dark arrow), delimited by a locally perceptible layer (light arrows), contains structures (arrowheads) similar to components in that F-cell central region (curved arrow), and that are locally overcast by homogeneous opaque material. (b): an element containing numerous patches of small opaque bodies (superimposed arrowheads) has its lucent delimiting layer heavily pervaded by filamentous structures (right hand side, thin arrows) reaching the outer opaque layer. Only this layer and an opaque band, confluent with that corresponding to the plasma membrane are discernible at the element extremity (curved arrow), which is marked by filamentous structures (enlarged in c, thin arrows). As also shown in c, the larger opaque bodies display groups of opaque particles (superimposed arrows) intermingled with smaller particles (arrowheads). The dark arrow points to a type of inclusion. (d): an opaque band (curved arrows), apparently discontinuous next to the host wall (short, dark arrow), contains a mass of homogeneous matter (long, dark arrow), surrounded by opaque particles (thin arrow). (e): the central region in this F-cell is delimited by only a faint thin band (arrowheads) approaching the cell periphery and its content is similar to the elements in $\mathbf{a}$ and $\mathbf{b}$, showing numerous small particles and larger structures with lucent cores (thin arrows) in its more opaque part. F, fungus; Pm, pit membrane. 
corresponding to the fungal cell periplasm. Hence, it would be indicated to determine whether an analogy exists between the EOBs and the OM under consideration, as well as between the lesser opaque bodies and numerous similar ones observed in host cell content in the same samples (not illustrated).

The occurrence of fungal cell wall modifications, including desquamation, in other wilt-causing fungi, has been described and reported previously (Nicole et al. 1994; Ouellette and Baayen 2000; Ouellette et al. 1999a, 1999b, 2002). In this study, fungal cell wall desquamation was also observed similar to that reported for O. novo-ulmi (Ouellette et al. 1999a), but in some cases, unevenness in the walls might also have been due to irregular wall formation.

In summary, a main aspect of infection in staghorn sumac plants by $F$. oxysporum f. sp. callistephi is related to the presence of large masses of OM that extend long distances in middle lamellae. These masses were associated with pronounced host tissue

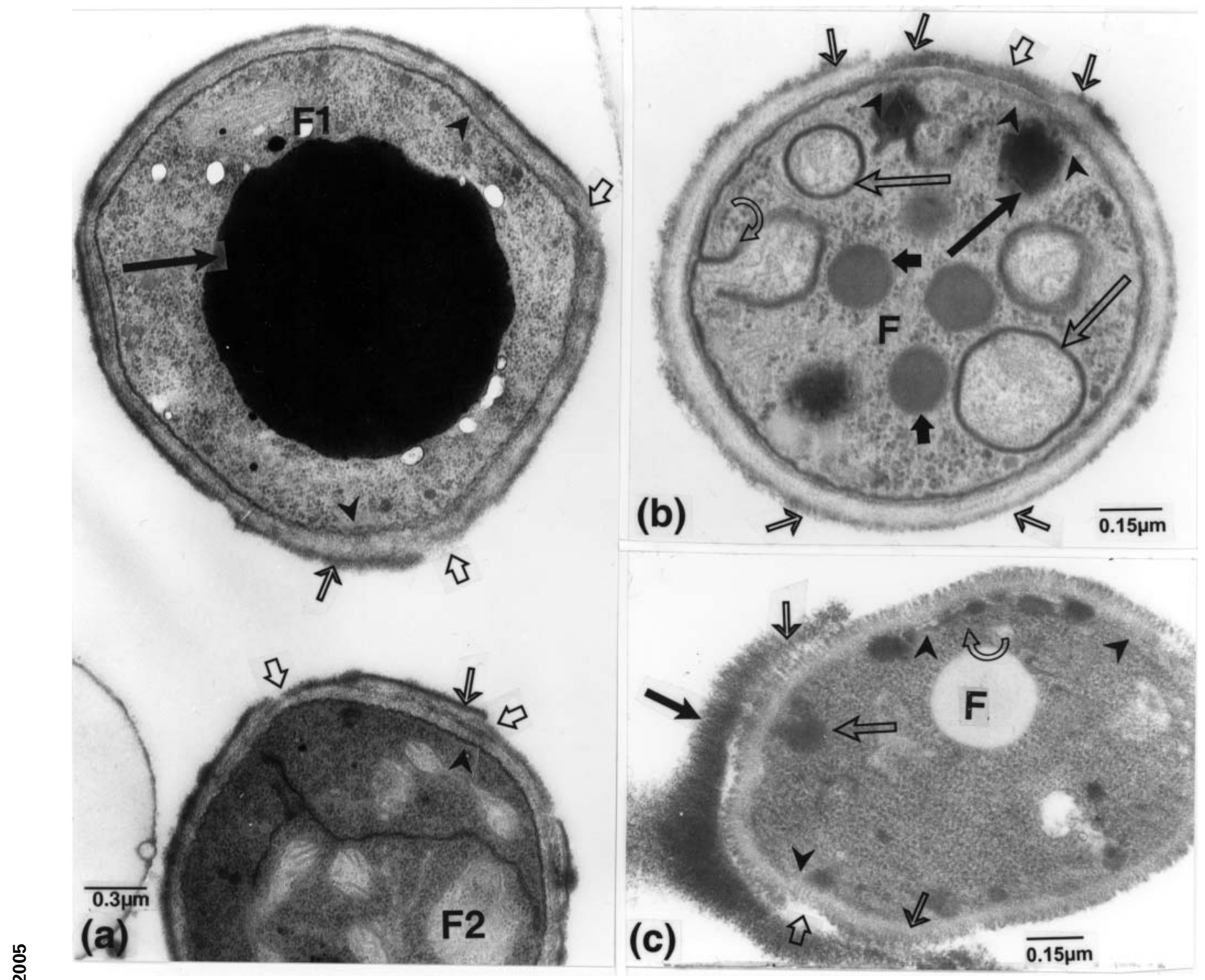

Figure 8. TEM of naturally infected sumac, incubated on an agar medium before fixing. Short, light arrows = wall irregularities in or desquamation of cell walls; thin arrows = fine filamentous structures in cell walls; and arrowheads = similar structures reaching from the cell periphery into the extracellular matter. (a): presence of a large EOB (arrow) in a F-cell. (b): in addition to EOBs (long dark arrow), presence of regular less opaque bodies (short dark arrows) in a F-cell. Areas with lighter content (long, light arrows) are delimited by opaque bands, seemingly originating from ingrowths of the plasma membrane (curved arrow). (c): a F-element filled with uniform opaque particles, some clouded by opaque material (long, light arrow). Other bodies occur in the element periphery, in the only region (curved arrow) displaying profile of a plasma membrane. The F-wall is striated with filamentous structures (arrowheads) which locally extend into a thick layer of extracellular matter (dark arrow) (which was also encircling another nearby cell). EOB, electron opaque body; F, fungus cell. 
alterations, particularly near the cambial area. As this matter frequently appeared to have no immediate connections with pathogen or host cell content, questions remain as to its origin. Due to the homogeneity of this matter, to its difference with normal or altered host cell content, to its uniform labelling for DNA, and to its similarity with content of some fungal cells, it seems warranted to investigate further about a pathogen origin.

\section{ACKNOWLEDGEMENTS}

We are thankful to Prof. R. Bauer and Dr. U. Simon, Universität Tübingen, Tübingen, Germany, and to Prof. K. Mendgen, Universität Konstanz, Konstanz, Germany, for their useful comments concerning the present observations. The technical editing of this paper by Ms. Pamela Cheers, Ms. Isabelle Lamarre and Mr. Benoit Arsenault was greatly appreciated. Mr. Alain Goulet provided valuable assistance in conducting the inoculation and TEM work. We are indebted to Dr. Ariane Plourde, former Research Director, and to the management of this Centre for providing facilities for completing this work. It was also supported in part by a NSERC research grant to the senior author.

\section{REFERENCES}

Atsatt, P.R. 2003. Fungus propagules in plastids: the mycosome hypothesis. Int. Microbiol. 6 : 1-21.

Carothers, Z.B. 1973. Studies of spermatogenesis in the Hepaticae. IV. On the blepharoplast of Blasia. Am. J. Bot. $60: 819-828$.

Chamberland, H. 1994. Gold labeling methods for the ultrastructural localization of host wall and pathogen components. Pages 1-11 in O. Petrini and G.B. Ouellette (eds.), Host wall alterations by parasitic fungi. APS Press, The American Phytopathological Society, St. Paul, MN, USA.

Chamberland, H., and G.B. Ouellette. 1977a. Formes d'inclusions osmiophiles dans les cellules de Ceratocystis ulmi. Can. J. Bot. 55 : 695-710.

Chamberland, H., and G.B. Ouellette. 1977b. Caractéristiques ultrastructurales de Ceratocystis ulmi en milieux naturel et artificiel. Can. J. Bot. 55 : 1579-1598.

Charest, P.M., G.B. Ouellette, P. Blais, and H. Chamberland. 2004. Irregular growth forms and cell wall modifications, polygalacturonase detection, and endocell formation in Fusarium oxysporum f.sp. radicis-lycopersici infecting tomato plants, as studied ultrastructurally and cytochemically. Mycol. Prog. 3 : 137-150.

Garrison, F., F. Mariat, K.S. Boyd, and H. Fromentin. 1977. Ultrastructural observations of an unusual osmiophilic body in the hyphae of Sporothrix schenckii and Ceratocystis stenoceras. Ann. Microbiol. (Institut Pasteur) 128B : 319-337.

Nicole, M., K. Ruel, and G.B. Ouellette 1994. Fine morphology of fungal structures involved in host wall alteration. Pages 13-30 in O. Petrini and G.B. Ouellette (eds.), Host wall alterations by parasitic fungi. APS Press, The American Phytopathological Society, St. Paul, MN, USA.

Ouellette, G.B. 1978. Light and electron microscope studies on cell wall breakdown in American elm xylem tissues infected with Dutch elm disease. Can. J. Bot. $56: 2666$ 2693.

Ouellette, G.B., and R.P. Baayen. 2000. Peculiar structures occurring in vessel walls of the susceptible carnation cultivar Early Sam infected with Fusarium oxysporum f. sp. dianthi. Can. J. Bot. 78 : 270-277.
Ouellette, G.B., and D. Rioux. 1992. Anatomical and physiological aspects of resistance to Dutch elm disease. Pages 257-307 in R.A. Blanchette and A.R. Biggs (eds.), Defense mechanisms of woody plants against fungi. SpringerVerlag, Berlin, Germany.

Ouellette, G.B., and D. Rioux. 1993. Alterations of vessel elements and reactions of surrounding tissues in the DED syndrome. Pages 255-292 in M.B. Sticklen and J.L. Sherald (eds.), Dutch elm disease research: cellular and molecular approaches. Springer-Verlag, New York, USA.

Ouellette, G.B., N. Méthot, H. Chamberland, C. Côté, and J.G. Lafontaine. 1995. Cytology of irregular growth forms of Ophiostoma ulmi and Ophiostoma novo-ulmi growing through millipore filter membranes and sterilized elm wood sections. Can. J. Microbiol. 41: 1095-1110.

Ouellette, G.B., H. Chamberland, A. Goulet, M. Lachapelle, and J.-G. Lafontaine. 1999a. Fine structure of the extracellular sheath and cell walls in Ophiostoma novo-ulmi growing on various substrates. Can. J. Microbiol. 45 : 582-597.

Ouellette, G.B., R.P. Baayen, M. Simard, and D. Rioux. 1999b. Ultrastructural and cytochemical study of colonization of xylem vessel elements of susceptible and resistant Dianthus caryophyllus by Fusarium oxysporum f. sp. dianthi. Can. J. Bot. 77 : 644-663.

Ouellette, G.B., R.P. Baayen, M. Simard, and D. Rioux. 2002. Reactions of paratracheal cells of resistant and susceptible carnation (Dianthus caryophyllus) cultivars to vascular invasion by Fusarium oxysporum f.sp. dianthi. New Phytol. 156 : 113-128.

Ouellette, G.B., D. Rioux, M. Simard, and M. Cherif. 2004a. Ultrastructural and cytochemical studies of hosts and pathogens in some fungal wilt diseases: retro- and introspection towards a better understanding of DED. In L. Gil, A. Solla, and G.B. Ouellette (eds.), New approaches to elm conservation. Investig. Agrar.: Sist. Recur. For. 13 : 119-143.

Ouellette, G.B., R.P. Baayen, D. Rioux, and M. Simard. 2004b. Peculiar ultrastructural characteristics of fungal cells and of other elements apposed to and in vessel walls in plants of a susceptible carnation cultivar, infected with Fusarium oxysporum f.sp. dianthi race 2. Phytoprotection $85: 121-138$.

Ouellette, G.B., D. Rioux, M. Simard, and R.P. Baayen. 2004c. Occurrence of paracrystalloids and their particles in resistant and susceptible carnation plants infected with Fusarium oxysporum f.sp. dianthi race 2. Phytoprotection $85: 139-151$

Ouellette, G.B., D. Rioux, M. Simard, H. Chamberland, M. Cherif, and R.P. Baayen. 2004d. Ultrastructure of the alveolar network and its relation to coating on vessel walls in elms infected with Ophiostoma novo-ulmi and in other plants affected with similar wilt diseases. In L. Gil, A. Solla, and G.B. Ouellette (eds.), New approaches to elm conservation. Investig. Agrar.: Sist. Recur. For. 13 : 147-160.

Ouellette, G.B., M. Cherif, M. Simard, and L. Bernier. 2005. Histopathology of Fusarium wilt of staghorn sumac (Rhus typhina) caused by Fusarium oxysporum f. sp. callistephi race 3. I. Modes of tissue colonization and pathogen peculiarities. Phytoprotection 86 : 157-174.

Park, P., H. Ishii, Y. Adachi, S. Kanematsu, H. leki, and S. Umemoto. 2000. Infection behavior of Venturia nashicolai, the cause of scab on Asian pear. Phytopathology $90: 1209-1216$

Renzaglia, K.S., S.B. Dengate, S.J. Schmitt, and J.G. Duckett. 2002. Novel features of Equisetum arvense spermatozoids insights into pteridophyte evolution. New Phytol. 154 : 159-174. 
